$(p=0.000), \quad 10.3$ for increased CRP $(p=0.002)$ and 11.3 for CF $(p=0.002)$. STIR MRI imaging assessment proved acceptable sensitivity (79\%), excellent specificity (94\%), and high PPV (88\%) for SPMRI $(p<0.001)$. WPMRI displayed better sensitivity $(87 \%)$ nonetheless, specificity $(67 \%)$ and PPV decreased $(59 \%) \quad(p<0.001)$. T1 MRI examination showed reasonable sensitivity (72\%) excellent specificity (97\%) and high PPV $(85 \%)$ for erosion $(p<0.001)$. Sensitivity for backfill was lower $(32 \%)$, but specificity (100\%) and PPV (100\%) were excellent $(p<0.001)$. Association, erosion and SPMRI pointed out a highly strong specificity (100\%) and PPV (100\%), however decreased sensitivity $(51 \%) \quad(p<0.001)$. Association, erosion and WPMRI significantly increased specificity (98\%) and PPV (94\%), although slightly decreased sensibility $(64 \%)(\mathrm{p}<0.001)$. Inter-observer agreement was higher for STIR MRI performance $0.70(95 \% \mathrm{CI} 0.59 ; 0.80)$, and lower for T1 0.47 (95\% Cl 0.35; 0.59).

Conclusion: At the onset, IBP, increased CRP, CF and IBD might be good indicators for selecting patients with a higher likelihood of positive diagnosis. Strongly positive SI MRI imaging is highly specific, brings acceptable sensibility and may be an excellent tool for early diagnosis of SPA. Weakly positive MRI STIR imaging might be helpful to detect patients with early SPA but lacks specificity. Early detection of erosion adds additional value to the STIR MRI reading, enhancing the specificity and increasing the probability of positive SPA diagnosis Disclosure of Interests: None declared

DOI: 10.1136/annrheumdis-2019-eular.1540

\section{SAT0359 THE AGREEMENT BETWEEN CT AND BONE SCINTIGRAPHY IN DETECTING OSTEOARTICULAR LESIONS IN SAPHO SYNDROME}

Yuqian $\mathrm{Ye}^{1}$, LI Chen ${ }^{2}$, Yihan $\mathrm{Cao}^{2}$, Wen Zhang ${ }^{2}$, Nan Wu'², Weihong Zhang ${ }^{3}$, Wenrui Xu ${ }^{2} .{ }^{1}$ Peking Union Medical College, Beijing, China; ${ }^{2}$ Peking Union Medical College Hospital, Beijing, China; ${ }^{3}$ Beijing Hospital, Beijing, China

Background: Computed tomography (CT) and ${ }^{99 m} \mathrm{Tc}-\mathrm{MDP}$ bone scintigraphy are commonly used to detect osteoarticular lesions and the typical bull's head sign of the anterior chest in the diagnosis of Sapho syndrome ${ }^{[1,2]}$. Since bone scintigraphy visualizes high radioactive uptake which basically indicates inflammatory lesions, and CT demonstrates the structural lesions in bones and joints, the findings of the two modalities usually do not correspond with each other ${ }^{[3,4]}$. However, little is known about the agreement between CT and bone scintigraphy on the findings of osteoarticular lesions in the patients of Sapho syndromes.

Objectives: To determine the agreement between CT and bone scintigraphy on the findings of osteoarticular lesions in Sapho syndrome.

Methods: A total of 68 patients who met the standard criteria of Sapho syndrome proposed by Kahn and Khan ${ }^{[5]}$ with simultaneous (the interval $<1$ month) whole spinal CT scan and bone scintigraphy were recruited in Peking Union Medical College from 2015 to 2016. Every CT or scintigraphy result was evaluated by at least two specialists independently and blindly. CT scan and scintigraphy results of all patients were evaluated for whether the following osteoarticular structures were involved: the clavicle, sternoclavicular joints, sternocostal joints, sacroiliac joints and all vertebra. The respective involvement frequencies and the kappa value of agreement were calculated.

Results: Involved vertebra on the CT scan present as corner lesions or endplate lesions. Involved joints on the CT scan present as narrowed articular spaces or damaged articular facets. CT scan is more sensitive to detect the involvement of vertebra and sternocostal joints, but less sensitive for sternoclavicular and sacroiliac lesions than bone scintigraphy. Kappa value was calculated to assess the agreement between CT and bone scintigraphy (Table. 1). It ranges from 0.103 to 0.593 over different structures, indicating a slight to moderate agreement between the two tests.
Table 1. Agreement analysis between CT and bone scintigraphy

\begin{tabular}{|c|c|c|c|c|c|}
\hline $\begin{array}{l}\text { Structures/ } \\
\text { Locations }\end{array}$ & $\begin{array}{l}\text { Involvement } \\
\text { frequency } \\
\text { on CT }\end{array}$ & $\begin{array}{c}\text { Involvement } \\
\text { frequency } \\
\text { on bone } \\
\text { scintigraphy }\end{array}$ & $\begin{array}{c}\text { Measure of } \\
\text { agreement, } \\
\kappa \text { value }\end{array}$ & $\begin{array}{c}\mathrm{P} \\
\text { value }\end{array}$ & \\
\hline $\begin{array}{l}\text { Cervical } \\
\text { vertebra }\end{array}$ & $14 / 68$ & $2 / 68$ & 0.209 & 0.055 & \\
\hline $\begin{array}{l}\text { Thoracic } \\
\text { vertebra }\end{array}$ & $29 / 68$ & $15 / 68$ & 0.103 & 0.343 & \\
\hline $\begin{array}{l}\text { Lumbar } \\
\text { vertebra }\end{array}$ & $33 / 68$ & $19 / 68$ & 0.464 & 0.001 & \\
\hline Sacral vertebra & $20 / 68$ & $3 / 68$ & 0.199 & 0.006 & \\
\hline Sternal angle & $27 / 68$ & $24 / 68$ & 0.593 & $<$ & 0.001 \\
\hline Clavicle & $3 / 68$ & $4 / 68$ & 0.248 & 0.039 & \\
\hline $\begin{array}{l}\text { Left } \\
\text { sternoclavicular } \\
\text { joint }\end{array}$ & $27 / 68$ & $36 / 68$ & 0.274 & 0.019 & \\
\hline $\begin{array}{c}\text { Right } \\
\text { sternoclavicular } \\
\text { joint }\end{array}$ & $26 / 68$ & $40 / 68$ & 0.209 & 0.06 & \\
\hline $\begin{array}{l}\text { Left } \\
\text { sternocostal } \\
\text { joint }\end{array}$ & $40 / 68$ & $6 / 68$ & 0.024 & 0.683 & \\
\hline $\begin{array}{l}\text { Right } \\
\text { sternocostal } \\
\text { joint }\end{array}$ & $39 / 68$ & $8 / 68$ & 0.075 & 0.283 & \\
\hline $\begin{array}{l}\text { Left sacroiliac } \\
\text { joint }\end{array}$ & $8 / 68$ & $14 / 68$ & 0.145 & 0.208 & \\
\hline $\begin{array}{l}\text { Right sacroiliac } \\
\text { joint }\end{array}$ & $9 / 68$ & $18 / 66$ & 0.415 & $<$ & 0.001 \\
\hline
\end{tabular}

The two tests have comparable detection rates for the involvement of sternal angle with a highest kappa value (0.593). But there are huge differences at other structures with extremely low kappa value, which suggests the routine bone scintigraphy for diagnosis cannot replace a CT scan in terms of evaluating osteoarticular lesions.

Conclusion: The agreement between CT and bone scintigraphy was poor, indicating an importance of implementing routine CT tests in Sapho syndrome.

\section{REFERENCES}

[1] Sugimoto H, Tamura K, Fujii T. The SAPHO syndrome: defining the radiologic spectrum of diseases comprising the syndrome. EurRadiol 1998:8:800-6.

[2] Salles M, Olive A, Perez-Andres R, Holgado S, Mateo L, Riera E, et al. The SAPHO syndrome: a clinical and imaging study. ClinRheumatol 2011;30:245-9.

[3] Akisue T, Yamamoto T, Marui T, et al. Lumbar spondylodiscitis in SAPHO syndrome: multimodality imaging findings. J Rheumatol 2002;29 (5):1100-1.

[4] Depasquale R, Kumar N, Lalam RK, et al. SAPHO: What radiologists should know. ClinRadiol 2012;67(3):195-206.

[5] Kahn MF, Khan MA. The SAPHO syndrome. BaillieresClinRheumatol 1994; 8:333-62.

Disclosure of Interests: None declared

DOI: 10.1136/annrheumdis-2019-eular.1095

\section{Psoriatic arthritis}

\section{SAT0360 REMISSION IN PSORIATIC ARTHRITIS: DEFINITION AND PREDICTORS}

Samar Al Harbi ${ }^{1}$, Ker-Ai Lee ${ }^{2}$, Vinod Chandran ${ }^{1}$, Richard Cook ${ }^{2}$, Dafna

D. Gladman ${ }^{1} .{ }^{1}$ University of Toronto, Toronto, Canada; ${ }^{2}$ University of Waterloo, Waterloo, Canada

Background: No validated definition of remission exists for psoriatic arthritis (PsA) to date. We previously identified $17.6 \%$ of our patients as 